\title{
Rats, Rooms and Riots: Usage of Space by Immigrants in the Dutch Town Utrecht 1945-1970
}

\author{
Marlou Schrover \\ History Department Leiden University, Leiden, The Netherlands \\ m.l.j.c.schrover@hum.leidenuniv.nl
}

\begin{abstract}
Immigrant access to space depended on the activities of local authorities, claim makers, journalists and firms. Together they shaped policies regarding immigrant housing, and more indirectly community formation. Local actors played a key role in migration governance, although they mostly did not work together. This article focusses on the Dutch town Utrecht, where housing was a major issue and immigrant housing was considered to be the worst in the Netherlands. When the number of immigrants was low, when employers arranged housing, and when the immigrants could be presented as much-needed workers, there were fewer protests. This article shows that immigrants lived where they were housed, where they could afford to, or were allowed to live, and only partly where they chose to live. Authorities attached value to the input of immigrant organisation, but most initiatives were for immigrants, rather than by immigrants.
\end{abstract}

\section{Keywords}

the local turn - housing - the spatial turn - Utrecht - Netherlands - guestworkers

\section{Introduction}

This article discusses policies and practices in relation to immigrants' access to and use of space, focussing on the Dutch town Utrecht in the period 1945-1970. The local level governance approach of this article, means I look at the city's local government, the press, employers, the police and immigrant organisations. Immigrants in Utrecht included Polish liberators, repatriates from the 
(former) Dutch East Indies, Hungarian refugees and guestworkers from Spain, Portugal, Italy, Greece, Morocco and Turkey. Utrecht is interesting because housing issues led to extensive debates, and according to some, the situation in Utrecht was worse than elsewhere. The period is interesting because severe housing shortages and labour shortages coincided: immigrants reduced the labour shortage and increased the housing shortage. In the mid-1970s, the economy declined and demand for labour decreased. This article analyses how access to space in Utrecht shaped relations between immigrants and non-immigrants, and how, when and why access to space changed. Space in this article relates mainly to living space (housing) and to a lesser extend to working space, and social space (including worshipping).

\section{Theory, Historiography and Material and Method}

In much of the governance literature, local actors are ignored. ${ }^{1}$ Policies are presented as made at the (inter)national level and implemented locally. ${ }^{2}$ In the last few decades, the role of national authorities in migration governance was rather large. However, in the early 1970s, local actors such as firms, municipal authorities, organisations, journalists and other claim makers played a crucial role in migration and integration policies because national policies were absent or deemed insufficient. ${ }^{3}$ The so-called local turn in governance is important because local actors were and are the ones who face challenges most directly. ${ }^{4}$ Immigrant housing is a policy field in which local actors could have influence.

1 Y. Ahouga, "The local turn in migration management: the IOM and the engagement of local authorities', Journal of Ethnic and Migration Studies 44:9 (2018) 1523-1540.

2 C. Bertossi, 'National models of integration in Europe: A comparative and critical perspective', American Behavioral Scientist 55:12 (2011) 1541-1561; P. Scholten, 'Between national models and multi-level decoupling: The pursuit of multi-level governance in Dutch and UK policies towards migrant incorporation', Journal of International Migration and Integration (2015) 1-22.

3 M. Schrover, 'Urban migration histories', in: T. Caponio, P. Scholten and R. Zapata Barrero (eds), Handbook of the governance of migration and diversity in cities (Abingdon and New York 2019) 22-38; C. Poppelaars and P. Scholten, 'Two worlds apart. The divergence of national and local immigrant policies in the Netherlands', Administration and Society 40: 4 (2008) 335-357; M. Bak Jørgensen, 'The diverging logics of integration policy making at national and city level', International Migration Review 46: 1 (2012) 244-278.

4 M.S. Hoekstra, J. Kohlbacher and D. Rauhut, 'Migration governance in three European cities: New local paradigms?', in: T. Lacroix and A. Desille (eds), International migrations and local governance: A global perspective (London 2018) 17-38; C.G. De Vito, 'History without scale: The micro-spatial perspective', Past \& Present 242:14 (2019) 348-372. 
According to the literature on the spatial turn approach, space determines social cohesion and processes of integration. ${ }^{5}$ The anthropologist Appadurai analysed how groups develop, maintain and imagine ties to a locality. Groups make claims to space by putting up monuments, community halls, shops, restaurants and places of worship. ${ }^{6}$ Spatial concentration does not equal community formation. People can live in the same neighbourhood without forming a community, and they can form communities without living near each other. ${ }^{7}$ Working together or spending free-time together influences community formation as much as living together does. Politics of space of national and local governments, housing corporations and architects, firms and organisations influence access and usage of space. These politics can include initiatives or permission to build a mosque, as well as protests against mosque building plans. ${ }^{8}$ Access to space changed because of population growth, changes in the population, the arrival of new migrants, and economic changes. This article looks at these aspects.

This article adds to the literature by looking at how access to space was problematised, and which claims were made and by whom. ${ }^{9}$ It is based on $35^{\circ}$ newspaper articles, the archive of the Demka steel factory (the largest employers of immigrants in Utrecht, and overall a large employer), the minutes of Parliamentary debates, and material from municipal archives. ${ }^{10}$ Together these

5 R. van Kempen and A. Seule Oezuekren, 'Ethnic segregation in cities: New forms and explanations in a dynamic world', Urban Studies 35:10 (1998) 1631-1656; M. Ellis, R. Wright and V. Parks, 'Work together, live apart? Geographies of racial and ethnic segregation at home and at work', Annals of the Association of American Geographers 94 (2004) 620-637.

6 A. Appadurai, 'Disjuncture and difference in the global cultural economy', Public Culture 2 (1990) 1-23; M. Schrover, 'Living together, working together: Concentrations amongst German immigrants in the Netherlands in the nineteenth century', Continuity and Change 18 (2003) 263-285.

7 M. Schrover and J. van Lottum, 'Spatial concentrations and communities of immigrants in the Netherlands 1800-19oo', Continuity and Change 22:2 (2007) 215-252.

8 J. Cesari, 'Mosque conflicts in European cities: Introduction', Journal of Ethnic and Migration Studies 3:6 (2005) 1015-1024; compare N. Bouras, Het land van herkomst. Perspectieven op verbondenheid met Marokko, 1960-2010 (Hilversum 2012).

9 For references see: H. Obdeijn and M. Schrover, Komen en gaan. Immigratie en emigratie in Nederland vanaf $155^{\circ}$ (Amsterdam 2008). For local level approaches see: I. van der Hoeven and M. Schrover, 'Een zorgzame of bemoeizuchtige werkgever? De AKU en haar Italianen', Jaarboek Gelre (2013) 185-214; G. van Os, Ik kwam met een koffer van karton. Spanjaarden in Zuidoost-Brabant 1961 - 2006 (Alphen aan de Maas 2006); E. van der Horst, Deventer Blik. Geschiedenis van arbeidsmigranten in een Nederlandse industriestad (1945-1990) (Deventer 2005); G. Mak, Sporen van verplaatsing. Honderd jaar nieuwkomers in Overijssel (Kampen 2000). For housing policies: J. Jansen, Bepaalde huisvesting. Een geschiedenis van opvang en huisvesting van immigranten in Nederland, 1945-1995 (Amsterdam 2006).

10 M. Schrover, J. ten Broeke and R. Rommes, Migranten bij de Demka-staalfabrieken in Utrecht (1915-1983) (Utrecht 2008). 
sources provide multiple voices, and make it possible to take a governance perspective. Much of the information comes from the local daily Het Utrechtsch Nieuwsblad and national newspapers such as Het Parool (former wartime resistance paper), Trouw (Protestant), De Volkskrant and De Tijd/De Maasbode (both aligned to the Catholic Party KVP), De Telegraaf (a right-wing populist paper), Het Algemeen Handelsblad and NRC (both liberal right-wing papers), Het Vrije Volk (paper of the Labour Party PvdA) and De Waarheid (paper of the Communist Party CPN). Het Vrije Volk, De Volkskrant and De Tijd/De Maasbode were affiliated with parties in power in this period, but they were nevertheless critical towards government policies. ${ }^{11}$ Seats in the Utrecht City Council in the period 1945-1970, were mainly held by the Labour Party $(\operatorname{PvdA})$ and the Catholic Party (KVP). The main point on the agenda of the mayor (Coen de Ranitz; not connected to a political party) was increasing the circulation of traffic, and therefore canals were filled up, streets broadened and buildings (including houses) torn down. ${ }^{12}$

\section{Public Enemy Number One}

Utrecht is a transport hub, a university town and a commercial and industrial centre. In the nineteenth, the elite lived in the city centre in large houses fronting on the canals, the middle class lived in smaller side streets, and the poor in back allies.

Until 1870, few houses were built outside the walls. Thereafter new neighbourhoods were built, which - like the old ones - were class heterogenous with upper- and middle-class families on the main streets and working-class families in side streets. After the new neighbourhoods were finished, the municipality demolished part of inner-city slums. ${ }^{13}$ Most new houses were built by corporations, whose goal was improving the housing situation of the people, not per se the poor. In 1910 the municipality started subsidising these building corporations. ${ }^{14}$

During the Second World War, the Nazis deported from Utrecht 10,00o people who were put to work as forced labourers in Germany, and 1600 Jews, of

\footnotetext{
11 M. Schrover, 'The deportation of Germans from the Netherlands 1946-1952', Immigrants \& Minorities 33: 3 (2015) 264-271.

12 H. Buiter, De moderne stad', in: R.E. de Bruin et al (eds), Een paradijs vol weelde, Geschiedenis van de stad Utrecht (Utrecht 2000) 435-501, 474.

13 La. F. Jens, Criminaliteit te Utrecht in verband met familie en wijk (Utrecht/Nijmegen 1940) 20-23.

14 Buiter, 'De moderne stad', 42.
} 


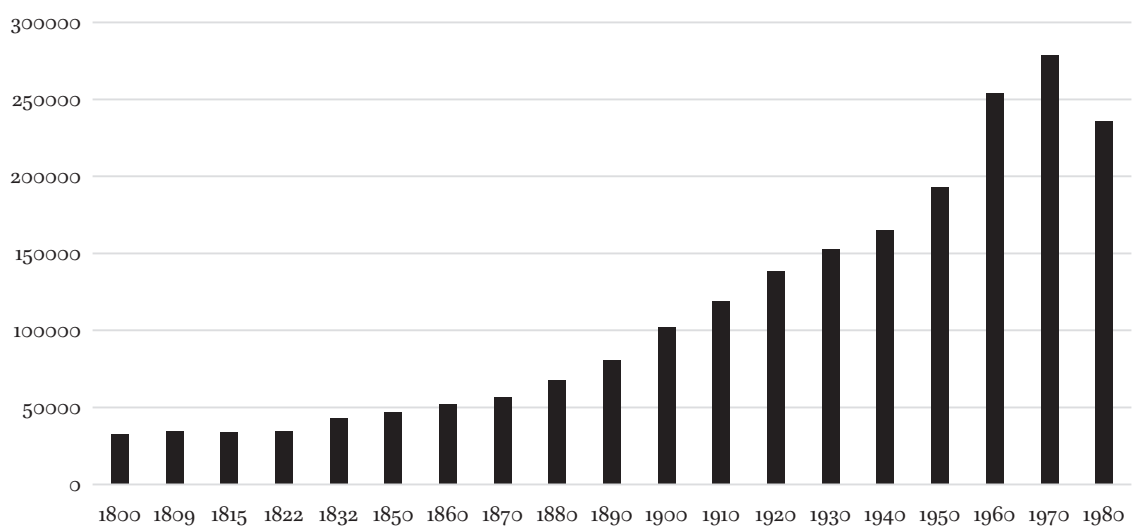

FIGURE 1 Population of the city of Utrecht 1800-1980.BASED ON CENSUS DATA.

whom 1200 were killed. ${ }^{15}$ In the Autumn and Winter of 1944 trains and buses stopped running, garbage was no longer collected, cinemas and schools closed and gas supply ended. People burned floorboards, banisters, and doors(posts) of their own homes to get some warmth. ${ }^{16}$ After the war, local newspapers wrote that the war had made people into paupers, who begged the liberators for chocolates and cigarettes. Women and girls showed too little modesty, marriages were ruined and virginity was lost at the large parties organised to celebrate victory and to entertain the soldiers. ${ }^{17}$ Polish, Canadian, British and American liberators were partly housed with families in Utrecht. Newspapers called on Dutch girls to show restraint. ${ }^{18}$ They should build families, and rebuild the nation. ${ }^{19}$ They should prefer nobody above their own people and they should be aware that war was a punishment of God. Did they want to be responsible for a continuation of war, one paper asked? ${ }^{20}$ The liberators might be heroes, but they were foreigners and therefore not suitable marriage partners.

After the war, the Netherlands - with a population of 10 million - was considered to be full. The Dutch government financed the emigration of 400,000

\footnotetext{
15 R. Rijksen, Criminaliteit en bezetting (Assen 1957) 45 and 80.

16 Buiter, De moderne stad', 471.

17 De Stem, 21 July 1945.

18 Kroniek van de week, 1 June 1945.

19 Parool 19 June 1945; Trouw 10 July 1945; Triomfklanken 18 May 1945; Het laatste nieuws van ver en dichtbij 21 February 1945.

20 Het vrije kanton 6 January 1945; Utrechtsch Katholiek Dagblad 11 June 1945.
} 
Dutch to overseas destinations like Australia and Canada. ${ }^{21}$ All political parties regarded the housing shortage as public enemy number one. ${ }^{22}$ This was the issue that dominated the news. During the war, 1573 houses in Utrecht were destroyed. ${ }^{23}$ Couples that had postponed their marriage because of the war, now married and a baby boom was expected. 100,00o Dutch soldiers who had fought in the Dutch East Indies (1946-1949), returned and wanted to start a family. An Utrecht alderman promised to help them find housing, but added he could not work miracles. ${ }^{24}$

In 1946, 3095 Utrecht families were looking for housing; in 1949 this had increased to $8081 .{ }^{25}$ In 1945, over 8 o per cent of Utrecht houses were rented; 75 per cent of those were owned by corporations. The middle and lower classes rented rather than owned a house. ${ }^{26}$ Both classes could rent the same type of house, because low-income families got rent support. ${ }^{27}$

In 1951, the Utrechtsch Nieuwsblad printed a long article about the housing shortage. ${ }^{28}$ Demand for housing increased to 9803: 33,603 people (a fifth of the Utrecht population) were on waiting lists for housing. Housing authorities forced people, who were living in houses that were too large for their household, to sublet. Municipal authorities presented a creative solution: citizens could lend money -4 million guilders were needed - to the municipality and solve the housing problem, create work for hundreds of people, and show solidarity. ${ }^{29}$ Authorities guaranteed that it was a good investment, with a fixed interest over a fifteen-year period. Bonds were sold for 100, 500 or 1000 guilders. According to the head of the Utrecht housing department, the consequences of the housing shortage was worse than that of unemployment in the 193os. Living conditions were dramatic. In one case, four families (2o people in total) shared a four-room house with one kitchen. Three to four children slept in one bed. Six years after the war, people should not live like this, the paper wrote. Men coming home from work found their wives in tears because they could

21 M. Schrover and M. van Faassen, 'Invisibility and selectivity. Introduction to the special issue on Dutch overseas emigration in the nineteenth and twentieth century', TSEG 7: 2 (2010) 3-31.

22 Obdeijn and Schrover, Komen en gaan, 282; Jansen, Bepaalde huisvesting 104-105.

23 Rijksen, Criminaliteit en bezetting, 36. War damage in Utrecht was not as large as in some other Dutch towns.

24 Utrechtsch Nieuwsblad 9 January 1950.

25 Utrechtsch Nieuwsblad 15 October 1949.

26 Jansen, Bepaalde huisvesting, 68.

27 Ronald van Kempen and Jan van Weesep, 'Segregation, housing and ethnicity in Dutch citles', Tijdschrift voor Economische en Sociale Geografie 88: 2 (1997) 188-195.

28 Utrechtsch Nieuwsblad 15 November 1951.

29 One guilder is about 0.5 euro. 
not cope. Children slept in attics that had not been boarded up: wind, rain and snow came in through broken roof tiles. The newspaper described how a family with five children lived in one room, with a leaking roof. A two-year old played on the damp floor, while its father cooked on a one burner stove. His wife was a cleaner, and he was an unemployed cripple. The father did read a newspaper, the journalist observed, adding that he was surprised it was not the communist daily. ${ }^{30}$ It was a veiled threat: the housing situation would drive people towards communism. Within four days the 4 million was raised. Overall, the housing shortage was given as a reason to discourage immigration as much as possible.

\section{Soldiers, Displaced Persons and Refugees}

There was consensus that the housing shortage was the biggest problem of the time. However, when labour shortages were discussed, housing issues were suddenly no longer mentioned. The Utrecht steel industry was important: it employed 40 per cent of the industrial workers. ${ }^{31}$ In 1947,48 per cent of the working population were workers, 30 per cent employees, and 12 per cent heads of firms. ${ }^{32}$ Because of labour shortages, the Utrecht steel industry got permission to recruit Displaced Persons (DPs) from camps in Germany. ${ }^{33}$ In newspaper articles about the recruitment of DPs the housing issue was not presented prominently.

Most DP s, that were recruited, were Poles. Initially, 200 Poles - part of the liberating troops - lived in Utrecht; this number doubled after the arrival of 200 DP s. ${ }^{34}$ The Poles were partly housed in the Polish Home in the city centre, which was the former Jewish orphanage. ${ }^{35} \mathrm{DP}$ s, who found private accommodation, brought their wives from Germany. All wanted to move into regular housing if they could. ${ }^{36}$ In 1948 a drunken Pole killed another Pole on the steps of the Polish Home. ${ }^{37}$ Another one forced his way into a bedroom, armed with

$30 \quad$ Utrechtsch Nieuwsblad 15 November 1951.

$31 \quad$ F. Baudet, Utrecht in bedrijf. De economische ontwikkeling van stad en regio en de Kamer van Koophandel, 1852-2002 (Utrecht 2002) 72-73; CBS, Beroepentelling 1971 (Den Haag 1971).

32 Rijksen, Criminaliteit en bezetting, 12.

33 Utrechtsch Nieuwsblad 24 May 1947; M. Schrover and T. Walaardt, 'Displaced persons, returnees and "unsuitables": the Dutch selection of DPs (1945-1951)', Continuity and Change 33 (2018) 413-440.

34 Waarheid 4 November 1946.

35 Situated on the Nieuwegracht.

36 Utrechtsch Nieuwsblad 14 May 1947.

37 Heerenveensche Koerier 31 May 1948; Waarheid 31 May 1948. 
an iron rod. Journalists in response asked if Poles were a threat to Utrecht society. The municipal employment agency however assured that these were incidents. Maybe five or six Poles were aggressive, and some had a hard time adjusting, but as workers they functioned well. ${ }^{38}$

Activities were organised to help the DP s. The Bishops Committee for Help to Refugees printed every fortnight 2000 copies of the paper Polak w Hollandii (Poles in Holland). It contained poems, short stories, and articles about Polish priests and writers who were terrorised in Poland. ${ }^{39}$ In 1949, a service was held for the small group of Latvian DPs in the Lutheran Church in Utrecht. ${ }^{40}$ The larger group of Catholic Poles could attend mass in Polish, which was, amongst others, celebrated by Josef Zelewski. He was a DP, who was recruited as a Demka worker, and who trained for priesthood in his spare time. In 1962, he was ordained and celebrated his first mass in Polish in the Utrecht Monica church. ${ }^{41}$

In 1952, the so-called Housewives Society of Utrecht (Vrouwen Comite Utrecht Hulp aan Ontheemden; VUHO) organised gatherings in support of DPS. They asked housewives to donate monthly 10 or 25 cents, or 1 guilder. Street monitors collected the money door to door, and gave it to block monitors, who gave it to district monitors. ${ }^{42}$ The vUHO said its activities were no more than a drop in the ocean, but they were important to women in camps in Germany. ${ }^{43}$ The vUно collected 13,00о guilders in four months. A quarter of all Utrecht women contributed to the campaign. The vU HO hoped to raise 25,00o guilders by the end of the year. They used the money to bring 20 Hungarian women from camps to Utrecht for a four-week holiday ${ }^{44}$ Afterwards, they returned to camp live without hope, family, and joy, Het Utrechtsch Nieuwsblad wrote. ${ }^{45}$ The gratitude of the women should encourage Utrecht women to donate more. ${ }^{46}$ Was it not cruel to send the women back, the vUHO asked newspaper readers rhetorically. Perhaps the women were better off if they had never seen the wealth 'we' live in? The vuно, however, thought it made the right choices: the women had been happy and had thanked the committee members in tears. ${ }^{47}$ The holiday

$38 \quad$ Utrechtsch Nieuwsblad 3 February 1948.

39 Waarheid 13 October 1948.

$40 \quad$ Leeuwarder Courant 22 April 1949.

41 Tijd/De Maasbode 14 July 1962.

42 Utrechtsch Nieuwsblad 6 March 1952.

43 Utrechtsch Nieuwsblad 30 April 1952.

44 Utrechtsch Nieuwsblad 17 October 1952.

45 Utrechtsch Nieuwsblad 10 November 1952.

46 Utrechtsch Nieuwsblad 14 November 1952.

47 Utrechtsch Nieuwsblad 18 November 1952. 
had made them feel human again. After a year enthusiasm dwindled and many volunteers stopped. ${ }^{48}$ The activities of the VUHO were important because they shaped later refugee support. The initiator of vUHO was Cateau s'Jacobs, who was the director of the Utrecht Foundation for Social Work..$^{49}$ s'Jacob had good contacts with the Dutch representative of the UNHCR, Cornelis Brouwer, and with the UN High Commissioner, Gerrit Jan van Heuven Goedhart, who visited VUHO and based UNHCR s refugee work on s'Jacobs activities. ${ }^{50}$

In 1956, after the Hungarian Revolt, Hungarian refugees came to Utrecht. Newspapers published hundreds of articles about them, but the housing issue was hardly mentioned, while the need for more workers was mentioned continuously. The 200 Hungarians in Utrecht were mostly employed by the Demka. ${ }^{51}$ VUHO helped to organise housing for the Hungarian refugees, ${ }^{52}$ but in newspapers this was not an important issue. Overall, it is clear that migrants did come to Utrecht, despite the housing shortage, and despite active attempts by the government to discourage people to come.

\section{Immigrants from the (Former) Dutch East Indies and Increased Diversity}

After 1949, 300,00o 'repatriates' came to the Netherlands from the Dutch East Indies/Indonesia. Housing now did become an issue. For the people from the former colonies, the 5 per cent rule applied: 5 per cent of the housing stock, over which Dutch authorities had a say, had to be made available to repatriates. The first repatriates found housing themselves, but 70 to 90 per cent of the later repatriates needed help finding housing. ${ }^{53}$ In 1958 , 1000 repatriated families lived in boarding houses scattered across Utrecht. ${ }^{54}$ Boarding house holders (who controlled 8o per cent of the beds) were aware that the housing shortage enabled them to make profit; the price per person rose form 4

48 Utrechtsch Nieuwsblad 15 May 1953; Utrechtsch Nieuwsblad 12 November 1953.

49 Stiching voor Maatschappelijk Werk. Utrechtsch Nieuwsblad 11 October 1955.

50 J. Koopmans, De Nederlandse Federatie voor Vrouwelijke Vrijwillige Hulpverlening en de vluchtelingenhulp na de Hongaarse Opstand Oorsprong en ontwikkeling van de vrouwelijke hulpverlening aan vluchtelingen 1951-196o (Master Thesis History Leiden 2016).

51 M. Schrover and T. Walaardt, 'The influence of the media on politics and practices: Hungarian refugee resettlement in the Netherlands in $195^{6}$, Journal of Migration History 3 (2017) 22-53.

$5^{2} \quad$ Utrechtsch Nieuwsblad 8 November 1956; Utrechtsch Nieuwsblad 14 March 1957.

53 Jansen, Bepaalde huisvesting, 73 .

54 Utrechtsch Nieuwsblad 8 November 1958. 
guilders, to 4,25 and 4,50. They wanted to put more children in a room than allowed and to provide heating only between 1 October and 1 May, regardless of outside temperatures. ${ }^{55}$

In March 1958, Utrecht had 250,00o inhabitants; growth was faster than anticipated. ${ }^{56} \mathrm{~A}$ social worker of a Protestant organisation urged the Utrecht population to show solidarity with repatriates. ${ }^{57} \mathrm{~A}$ journalist recorded a conversation between what he called a 'Dutch Dutch' and an 'Indo Dutch'. The Dutch Dutch person asked if repatriates were not taking the houses the Dutch needed so badly themselves. The Indo Dutch replied: 'you have lived with us for 350 years, now we can live here for a while'. Indo Dutch were citizens as much as the Dutch Dutch were, the head of the repatriation committee pointed out. They had rights to housing and should not be discriminated against. ${ }^{58}$ The repatriates were not discussed in newspapers as potential workers, who could solve the problem of labour shortages.

In the next years diversity increased. In 1962 there were 2700 foreigners in Utrecht with 43 different nationalities, including 328 Italians, 95 Spaniards, 200 Hungarians, 400 Germans and 150 Poles. In addition, there were people from Albania, Angola, Brazil, Ceylon, Columbia, Denmark, India, Jordan, Pakistan, Syria, Thailand and Turkey. Civil servants spoke French, German, English, Spanish, Malay and Russian. The Utrecht police tried to monitor newcomers. A newspaper presented this task as it was a spy novel: the man in the office of Alien Police was dressed decent but shabby. Was he who he said he was? Did he actually come from behind the Iron Curtain? Did he have a right to political asylum? The civil servant was trying to find out. His story sounded reliable, but the civil servant was unsure. He made the man tell his story to a second employee, and a third, and compared the stories: was the route the same in all three stories? Did details match? The civil servants concluded that the man lied and he was brought across the border. ${ }^{59}$ As was the case earlier, immigration was still discouraged, and newcomers were distrusted.

55 Telegraaf 21 September 1962; Utrechtsch Nieuwsblad 21 September 1962.

56 Utrechtsch Nieuwsblad 7 March 1958; Two years later the number hat increased to 253,200 but part of this growth was the result of annexations of (parts of) neighbouring villages.

57 Utrechtsch Nieuwsblad 11 January 19582.

58 Utrechtsch Nieuwsblad 9 May 1960.

59 Utrechtsch Nieuwsblad 18 August 1962. 


\section{Arrival of Guestworkers}

In the 196os, the large houses in the city centre, originally built for the elite, had fallen into disrepair and were converted into dwellings for either guestworkers or students. The number of students in Utrecht increased from 7000 in 1960 to 20,000 in 1975 . Students lived with landladies, or in student houses scattered across town. There was no campus housing. ${ }^{60}$ People were willing to let rooms to students or guestworkers to supplement their income, but when incomes increased, fewer people were willing to do so. Between 1963 and 1973 houses in the city centre were destroyed to build a shopping mall. ${ }^{61}$

About 8 o per cent of guestworkers were men. Women were also recruited, but in small numbers, and from different countries and for different jobs. ${ }^{62}$ In 1964, for instance, 25 women from the Philippines arrived in Utrecht to reduce the shortage of nurses. The 'girls', newspaper wrote, were aged 23 to 33 and were highly skilled. They were housed in the nurses' home of the hospital, they got Dutch lessons, and a mentor was assigned to them, who took them sightseeing and instructed them in Dutch customs. ${ }^{63}$ Their arrival did not lead to debates about housing because they formed a small group and the hospital provided housing.

Before the start of guestworker recruitment, firms had tried to attract workers from Dutch provinces, where there was unemployment, by promising housing. ${ }^{64}$ The Demka factory, for instance, said it had 100 family apartments available. Few people showed interest, and therefore firms looked for workers in Germany and Belgium, and when that failed in Spain, Portugal, Italy, Greece, Yugoslavia, Turkey and Morocco. ${ }^{65}$ Recruiters also looked at the Dutch colonies. In 1964, for instance, 30 workers from the Dutch Antilles arrived in Utrecht. A civil servant greeted them and said they would be able to learn a lot. They could transfer their knowledge to their children, of whom they had many, according to a newspaper, so that the next generation would not have to come to the Netherlands. The Antillean workers got a Dutch meal and map of Utrecht. They were housed with landladies, and as close to each other as

6o In the 1970s two large complexes became available to students.

61 Buiter, De moderne stad', 474.

62 M.B. Chotkowski, "Baby's kunnen we niet huisvesten, moeder en kind willen we niet scheiden". De rekrutering door Nederland van vrouwelijke arbeidskrachten uit Joegoslavië, 1966-1979', Tïdschrift voor Sociale Geschiedenis 26:1 (2000) 76-103.

63 Utrechtsch Nieuwsblad 31 October 1964.

64 Schrover, Ten Broeke en Rommes, Migranten bij de Demka-staalfabrieken.

65 W. Tinnemans, Een gouden armband. Een geschiedenis van mediterrane immigranten in Nederland, 1945-1994 (Utrecht 1994). 
possible, so that they would not be lonely. Experiences were good, newspapers wrote: 70 per cent functioned excellent, 28 per cent had adjustment problems, and only 2 per cent had to be send back. The plan was to recruit more workers, but this did not happen for reasons unknown. ${ }^{66}$ Utrecht firms also recruited 40 Armenian workers with Persian nationality. They had worked in Indonesia as oil pipe welders, and spoke Dutch. ${ }^{67}$ The largest groups of guestworkers however came from Spain, Portugal, Italy, Greece, Yugoslavia, Turkey and Morocco (see table 1).

Employers were only allowed to recruit workers if they provided housing. If workers came without being recruited, employers were however not responsible for their housing. Only guestworkers who were single or who left their families behind, could be recruited, so as to make sure that they would not burden the stock of family houses. According to the minister of Social Affairs, recruitment of guestworkers was crucial to economic growth: the Netherlands should be attractive to guestworkers and that meant they should be allowed to bring their families, as they could in other countries such as Germany. ${ }^{68}$ The ministry of Justice, however, opposed to family migration because it feared that would lead to permanent settlement. Furthermore, the minister of Justice said restrictions were needed to protect immigrant families against intolerable

TABLE 1 Guestworkers in Utrecht 196o-1971 (largest groups only)

\section{Year Italians Spaniards Greeks Yugoslavs Turks Moroccans}

\begin{tabular}{rrrrrrr}
\hline 1960 & 148 & 5 & & & & \\
1961 & 328 & 95 & & & & \\
1962 & 336 & 83 & 33 & 7 & 0 & 1 \\
1963 & 469 & 296 & 102 & 9 & 2 & 1 \\
1964 & 431 & 458 & 608 & 10 & 78 & 12 \\
1965 & 414 & 768 & 572 & 11 & 336 & 152 \\
1966 & 463 & 1405 & 668 & 12 & 838 & 1726 \\
1967 & 460 & 1348 & 637 & 12 & 921 & 2054 \\
1971 & 425 & 1660 & 965 & 80 & 1150 & 3030 \\
\hline
\end{tabular}

Based on Information from a Large Number of Newspaper Articles.

66 Utrechtsch Nieuwsblad 8 September 1964.

67 Utrechtsch Nieuwsblad 8 October 1963.

68 M. Schrover and S. Bonjour, 'Public debate and policy-making on family migration in the Netherlands, 1960-1995', Journal of Ethnic and Migration Studies 41:9 (2015) 1475-1494. 
housing conditions. ${ }^{69}$ According to the Catholic Party (KVP) it was morally wrong to separate husbands and fathers from wives and children. ${ }^{70}$ In January 1962, the ministry of Justice discovered that some Spanish wives had joined their husbands in Utrecht. They came on tourist visa, and had been granted a work permit after they found work. ${ }^{71}$ In September 1962, the ministry of Justice decided to deport seventeen of the women. It led to large debates in newspapers. ${ }^{72}$ According to some papers a precedent would be created if women were allowed to stay. If these women could stay, many other women would follow, newspapers warned, and the housing shortage would increase. ${ }^{73}$ Other papers, however, warned that if women were not allowed to stay, men might leave with the women. ${ }^{74}$ The Spanish women, 'who had arrived illegally by the dozens', according to De Telegraaf, should also not be deported because this would affect the working power of the men. ${ }^{75}$

In October 1962, newspapers reported that 20 Spanish women had been allowed to stay, 'for now' ${ }^{6}$ According to De Tijd/De Maasbode women, who had been deported, had not gone to Spain but to Germany, which allowed guestworkers to bring their families. When the rumour spread that the women would be able to return to the Netherlands, 15 women 'some with a baby in their arms' turned up at the Spanish community centre in Utrecht. Spanish songs were sung, accompanied by guitar music, journalists wrote. Some Spanish men left for Germany in the middle of the gathering to collect their wives as well, the paper added. ${ }^{77}$ However, according to the chief of the Utrecht Alien Police, Spanish women were not returning to Utrecht in large numbers, simply because hardly any had left. ${ }^{78}$ The decision to let women stay

69 Telegraaf 27 October 1962.

$70 \quad$ Schrover and Bonjour, 'Public debate and policy-making, 1475-1494.

71 M. Schrover, 'Verschillen die verschil maken: Inleiding op het themanummer over gender, migratie en overheidsbeleid in Nederland en België in de periode 1945-2005', TSEG 5: 1 (2008) 2-22.

72 Parool 27 September 1962; Vrije Volk, 27 September 1962; Tijd, 26 September 1962, PZc 26 September 1962; Vrije Zeeuw 26 September 1962; Gereformeerd Gezinsblad 27 September 1962; Limburgs Dagblad 26 September 1962; Vrije Volk 26 September 1962; Waarheid 26 September 1962.

73 Tijd/De Maasbode 26 September 1962; NRC, 26 September 1962; PZC 26 September 1962; Vrije Zeeuw 26 September 1962; Telegraaf 27 October 1962.

74 Parool 27 September 1962; Vrije Volk 27 September 1962; Tijd/De Maasbode 29 October 1962; Telegraaf 6 October 1962.

75 Telegraaf 6 October 1962.

$76 \quad$ Nieuwsblad van het Noorden 4 October 1962.

77 Tijd/De Maasbode 8 October 1962.

78 Nieuwsblad van het Noorden 8 October 1962; Telegraaf 4 October 1962. 
was met with enthusiasm in the 'Spanish camp' in Utrecht, De Telegraaf added, but it made the housing problem acute. ${ }^{79}$ Het Vrije Volk wrote that recently Greek guestworkers had arrived in Utrecht, and they posed a new problem of an unpredictable nature. ${ }^{80}$ Thereafter, government rules for family reunification were relaxed, but guestworkers had to have housing suitable for a family before they could bring their families. Overall, in the case of the guestworkers, debates were about housing and labour shortages. The rather large number of guestworkers, and the increase in the number of students, who also sought places to live explain this.

\section{For Immigrants, not by Immigrants}

The Dutch government held employers responsible for housing as well as for the well-being of the recruited guestworkers. Employers delegated the welfare task to Catholic charities, which branched out their activities to non-Catholic guestworkers from Morocco and Turkey. ${ }^{81}$ The employers initially funded the charities. ${ }^{82}$ Initiatives were developed for guestworkers, not by them. In 1960, an Utrecht chaplain, who worried about the wellbeing of the Italian guestworkers, reached out to the Catholic Institute for Social Work, which started a consultation hour for Italians. ${ }^{83}$ The Utrecht Provincial Social Caritive Centre ${ }^{84}$ created a support Committee for foreign workers in Utrecht ${ }^{85}$ run by volunteers. Two years later, the Catholic Institute for Social Work in Utrecht ${ }^{86}$ asked the municipality for a subsidy for a social worker for foreign workers: they got 40 per cent subsidy. ${ }^{87}$ In 1964, the Utrecht Support organisation for Foreign Workers was set up (Stichting Bijstand Buitenlandse Werknemers sввW). It played a key role in all migration debates in the years that followed. The sввw had a yearly turnover of 180,00o guilders, which was meant for advising foreign workers and mediation. The Ministry of Social Work gave a subsidy of 155,000

79 Telegraaf 9 October 1962; See also Friese Koerier 9 October 1962.

8o Vrije Volk 22 November 1962.

81 Parliamentary Papers (PP) Proceedings, session 2003-2004, 28 689, no. 12, 244.

82 Schrover, Ten Broeke and Rommes, Migranten bij de Demka-staalfabrieken.

83 L.S.J. Buis, 'Buitenlandse arbeider buiten de poort', in: R. Wentholt, Buitenlandse arbeiders in Nederland. Een veelzijdige benadering van een complex vraagstuk (Leiden 1967) 154-166.

84 Het Provinciaal Sociaal Charitatief Centrum.

85 De Commissie Bijstand Buitenlandse Werknemers.

86 Het Stichting Katholiek Instituut voor Maatschappelijk Werk Utrecht.

87 The Utrecht Municipal Archive (UMA) 1007-3, 26199: 17 April 1964. 
guilders, while Utrecht firms jointly paid $25,000.88$ The SBBW distributed brochures about the position of women in Morocco, about family life and marital law. ${ }^{89}$ Director of the sв вw was L.S.J. (Lorentius) Buis. He was very active, published on guestworker migration, and met with a large number of policy makers and migration researchers..$^{90}$ Two Utrecht doctors, who were also aldermen - Goddefroy (PvdA) and Hardy (KVP) - also made claims because they worried about the spread of venereal disease.${ }^{91}$ According to Hardy there were hardly any cases until five years before, but thereafter there was an increase and all cases related to Dutch 'girls', who had relationships with Turks, Spaniards or Italians.

In the 1970s the Dutch government decided to centralise activities of organisations for guestworkers for efficiency reasons. By 1975 government subsidies had increased to 100 per cent, and government influence increased..$^{92}$ General welfare organisations (not for immigrants) started to do less for immigrants and as a result the gap between immigrants and non-immigrants widened. ${ }^{93}$ Bottom-up initiatives of guestworkers competed with top-down initiatives of organisations subsidised and initiated by Dutch authorities. Language classes in Italian, set up by Italian guestworkers themselves outside schools and school hours, were moved, for instance, by municipal authorities into schools and were given during school hours. Italian organisations protested against this because they feared that their children might fall behind if they missed part of the Dutch curriculum. Children of guestworkers were placed in so-called concentration schools; one school taught all Spanish children, another one all Turkish children and so on. In the Netherlands, most children walk or bike to school. The concentration of immigrant children in concentration schools, further away from where they lived, meant segregation from other children in their neighbourhood. ${ }^{94}$ After three years of protests, the Italian classes were removed from the schools, but those for other groups stayed.

In 1975 the minister of Social Work pressed for more representation of guestworkers in the organisations. This was surprising as only one year earlier authorities were of the opinion that guestworkers were not suitable for

88 Utrechtsch Nieuwsblad 14 October 1967.

$89 \quad$ Nieuwsbrief Buitenlandse Werknemers 1969156.

9o Wentholt and others, who worked at the Leiden University sociology department.

91 UMA, no. 1007-3, 26199: Vrij Nederland 12 December 1964.

92 PP Proceedings, session 2003-2004, 28 689, no. 12, 127-128, 244.

93 R. Rijkschroeff, J-W. Duyvendak and T. Pels, Bronnenonderzoek integratiebeleid (Den Haag 2004) 26.

94 M. Schrover, 'Pillarization, multiculturalism and cultural freezing, Dutch migration history and the enforcement of essentialist ideas', BMGN / LCHR 125: 2/3 (2010) 329-354. 
managerial positions within the organisations. The organisations did not present candidates, and nothing changed..$^{95}$ Guestworkers protested against the lack of influence. Left-wing Dutch students and other Dutch volunteers joined these protests and called policies patronising and colonial. ${ }^{96}$ Left-wing guestworkers, and the students and other volunteers set up immigrant Councils (Raden), ${ }^{97}$ which called the existing organisations old-fashioned. The Councils were, like existing organisations, fully subsidised by the government. ${ }^{98}$ The Councils did include representatives of immigrant groups, but never as part of their management. ${ }^{99}$

The existing organisations and the new Councils competed with each other for government subsidies and for the right to represent guestworkers. ${ }^{100}$ The Councils favoured left-wing initiatives, but also competed with left-wing initiatives by the immigrants themselves, while it successfully protested against subsidies for religious organisations set up by guestworkers. ${ }^{101}$ In 1975 elections were organised for the Utrecht Council. Because right-wing guestworkers proved to be better organised than their left-wing countrymen, all elected guestworkers representatives in the Councils were right-wing. ${ }^{102}$ A clash with the left-wing Dutch volunteers followed, and that signalled the end of the Councils. Overall, this organisational battle - in which the guestworkers had little voice - frustrated finding a solution for the housing issue.

95 PP Proceedings, session 2003-2004, 28 689, no. 12, 127-128, 138.

96 PP Proceedings, session 2003-2004, 28 689, no. 12, 140, 142, 253.

97 Belangenraad Buitenlandse Werknemers or Migrantenraad; 1973 in Utrecht, 1974 in Dordrecht, 1976 in Gouda, and in 1978 in Delft.

98 PP Proceedings, session 2003-2004, 28 689, no. 12, 138, 142.

99 Marlou Schrover and Floris Vermeulen, 'Immigrant organisations. Introduction', Journal of Ethnic and Migration Studies 3 (2005) 823-832.

100 W. Tinnemans, Een gouden armband. Een geschiedenis van mediterrane immigranten in Nederland, 1945-1994 (Utrecht 1994) 238.

101 PP Proceedings, session 2003-2004, 28 689, no. 12, 247; Nicolaas Landman, Van mat tot minaret. De institutionalisering van de Islam in Nederland (Amsterdam 1992); T. Sunier, 'Moslims in de Nederlandse politieke arena', in: T. Sunier, J. W. Duyvendak, S. Saharso and F. Steijlen (eds), Emancipatie en subcultuur: sociale bewegingen in België en Nederland (Amsterdam 2000) 138-157; PP Proceedings, session 2003-2004, 28 689, no. 12, 139, 141; Penninx and Schrover, Bastion of bindmiddel. 


\section{Bedouin Camps and a Mosque}

Around 1965, unemployment increased and thousands of jobs disappeared when firms mechanised. ${ }^{103}$ Demand in the steel industry was highly instable and this influenced the housing issue. ${ }^{104}$ In 1965 , housing of guestworkers in Utrecht led to debates which were covered extensively by local and national newspapers. Guestworker migration was called an invasion, ${ }^{105}$ and guestworker lodgings were called Bedouin camps. ${ }^{106}$ Especially the arrival of non-recruited guestworkers led to problems because their employers were not responsible for their housing. In 1965, civil servants said that half of the guestworkers in Utrecht had been recruited, ${ }^{107}$ but a research found that only 16 per cent of the 4500 foreign workers were recruited. ${ }^{108}$

Guestworkers in Utrecht changed jobs and housing frequently. According to Buis, guestworkers moved jobs if they could earn 2 cents more. Turks and Moroccans moved house because they wanted to live together, because they could save on rent, or because they could cook themselves and avoid pork, said Buis. ${ }^{109}$ The Moroccan cook, interpreter, and social worker Simane Souhmy, who was married to a Dutch nurse, challenged the idea that Moroccans preferred living together; they had no choice and were exploited. ${ }^{110}$ According to Buis, 8 o men lived in a house on the main canal, the Oudegracht, and together paid a monthly rent of 6000 guilders. Letting rooms was very profitable. ${ }^{111}$ Slum lords benefitted from the fact that some people were not willing to let rooms to foreigners, De Waarheid added. ${ }^{112}$

New guestworkers kept coming despite of the housing shortage. The Utrecht municipal employment agency got the reputation, among employers and workers, that they were working fast. Guestworkers arrived at Utrecht's Central railway Station with some money, and unable to speak any language apart from their own. They had the address of the employment agency, station

\footnotetext{
103 Utrechtsch Nieuwsblad 8 January 1963.

104 Statistische berichten gemeente Utrecht.

105 Virginie Mamadouh, 'The scaling of the 'Invasion': A geopolitics of immigration narratives in France and The Netherlands', Geopolitics 17 (2012) 377-401.

106 N. W. Soetens, Gastarbeiders, wat heeft het hun gebracht? Autobiografisch verslag over het Aktiekomitee Pro Gastarbeiders (Rotterdam 2008). UMA, Archive 1813-1969 no. 22815, map Nota chefs V.H., M.A. en Econoom inz. Buitenlanders.

108 Tinnemans, Gouden armband, 68.

109 Utrechtsch Nieuwsblad 22 May 1965.

110 Utrechtsch Nieuwsblad 20 November 1965.

111 Utrechtsch Nieuwsblad 22 May 1965.

$112 \quad$ Waarheid 27 July 1965.
} 
masters pointed them in the right direction, and the agency placed them in a job within a day or even within hours. Guestworkers were surprised by this fast service as well as by the fact that they did not have to pay for it. ${ }^{113}$ Guestworkers frequently arrived in the evening, and tried to find a countryman willing to take them home, where the landlady or -lord agreed to let them stay the night. The next day they told the employment agency that they had found housing, whereupon they got a work permit.114

In June 1965 , the housing situation worsened, but the municipality held on to the view that it was not responsible for housing guestworkers. ${ }^{115}$ If bad houses were closed down, workers would be on the streets, the municipality warned. In July 1965, civil servants calculated that clearing the worst houses would mean a reduction of 182 beds; 182 people would have to find alternatives. ${ }^{116}$ Attention focussed on Moroccan migrants. In 1965 Muhammad Mashish Alami, who taught Arabic at a University in Salamanca and who was a journalist for the Moroccan paper Al-Alam, wrote an article for the Utrecht newspaper. There were about 300 Moroccans in Utrecht, most of whom had arrived with a piece of paper which simply said 'Utrecht station'. They did not intend to stay; they only wanted to earn money fast and return. They had left their sunny country and loved ones behind. Most had five to six people to support in Morocco. After arrival, they felt isolated. Housing and hygiene were dreadful and some had tuberculosis. The Moroccan workers wanted to get in touch with the Dutch, but did not know how. Therefore, they drifted towards the Central Station, where they could sit and watch people come and go. ${ }^{117}$ Moroccans knew they would meet others there and via the railways they felt connected to their country of origin, according to newspapers. They also watched out for new arrivals, whom they could help find work and lodging. ${ }^{118}$

In 1965 , the Utrecht municipality again took stock of the housing situation of guestworkers, and reported on 287 accommodations with 2226 workers (on average 7.6 persons per house). Most of the accommodations had 1 or 2 beds, but there were some with 50 to 82 beds. Guestworkers slept in sheds, basements or in overcrowded rooms, which were extremely dirty and a fire hazard. In one house, a worker slept in a pigeon coop. Neighbours complained about noise and a rat plague. A second investigation into 347 houses with 2400

\footnotetext{
113 Utrechtsch Nieuwsblad 21 February 1964.

114 Utrechtsch Nieuwsblad 22 May 1965.

115 UMA, Archief gemeentebestuur 1813-1969 nr. 22815, map Vragen mevr.J.M. Donia-Brugman.

116 UMA, Archief gemeentebestuur 1813-1969 nr. 22815, map Vragen mevr.J.M. Donia-Brugman.

117 Utrechtsch Nieuwsblad 13 August 1965.

$118 \quad$ Utrechtsch Nieuwsblad 14 October 1967.
} 
guestworkers showed 6o houses needed repairs and 30 owners were instructed to make changes. ${ }^{119} 75$ Turks were forced to leave their house, and employers were asked to provide alternative housing. ${ }^{120}$

Things did not improve. A third investigation by the municipality showed 14 guestworkers lived in an attic, while 18 lived in a garage measuring 40 square meters. They cooked their meals on a burner stove in the middle of the room. The owner had made a hole in the wall, enabling the workers to use the toilet in his house. Employers were asked again to find better housing, but the problem was that workers changed jobs frequently, and employers did not feel responsible. ${ }^{121}$ Again boarding houses were closed down and this time 29 Turks ended up on the street. ${ }^{122}$ Bad housing was mentioned in the same context as tuberculosis. ${ }^{123}$ Ill workers were less productive and might infect Dutch people. ${ }^{124}$

Buis argued in favour of a selection station on the Dutch-Belgian border where Moroccans could get a health check. ${ }^{125}$ The plan was labelled undoable. In 1968 it, however, resurfaced. Employers would be informed about the supply of workers, and they could only recruit workers from the selection station. ${ }^{126}$ Buis also argued in favour of collective housing, which would make it possible to monitor workers. Problems were tuberculosis, contacts with Dutch girls, visits to prostitutes and robberies. If the workers were housed collectively, for instance in barracks, there would be fewer problems, according to Buis. Within three years, the number of foreign workers had increased from 466 to 4108 . The situation was going from bad to worse, especially with the Moroccan workers, according to Buis. Several social workers predicted violence and conflicts. ${ }^{127}$ A booklet presented race riots as a likely scenario. Churches and trade unions were doing too little to help foreign workers, its author said. ${ }^{128}$

The secretary of state of Social Affairs Cees Egas (PvdA) insisted housing was the responsibility of employers. In his view the problem was that especially the Moroccans were unorganised and thus could not make demands regarding housing. ${ }^{129}$ State secretary for Social Affairs J.F.G.M. de Meijer (KVP) said

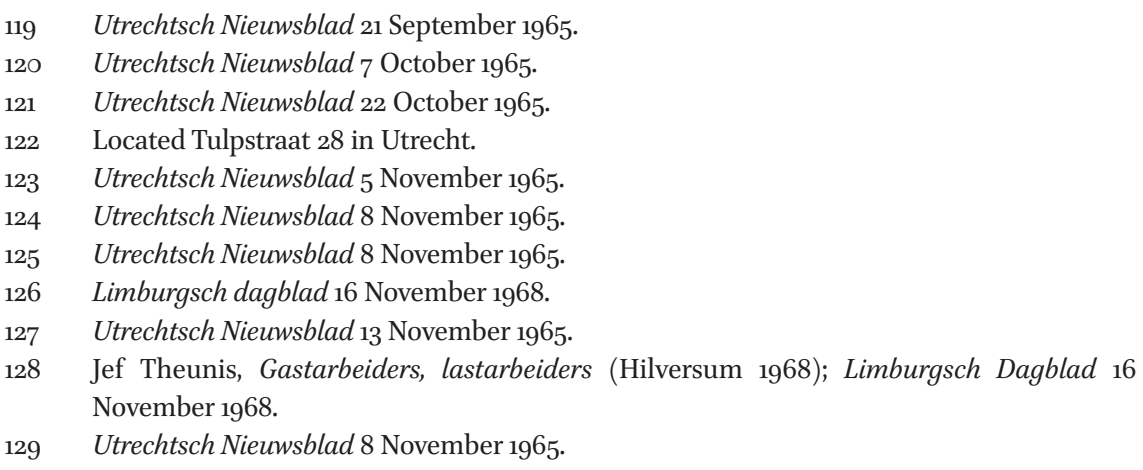


in Parliament - voicing employer views - that Buis exaggerated. Only 10 per cent of the guestworkers had housing problems. Buis disagreed: guestworkers were sleeping on the floor, or two in a bed. Clearance of boarding houses had increased the misery. ${ }^{130}$ House owners charged 25 guilders per week per bed. According to Buis, the claim about 10 per cent was based on nothing. ${ }^{131}$

A guestworkers 'warehouse' on the Oudegracht was cleared. There were 81 beds, some of which were used double; workers who worked the nightshift left their beds still warm for those who worked the dayshift. The landlady charged 17,5 O per bed per week (amounting to a yearly income of 75,000 guilders). The workers cooked in the kitchen, in the corridors and in the rooms. They used the roof gutter to get from one room to another because corridors were blocked. ${ }^{132}$ There were 11 guestworker 'warehouses' on the Oudegracht and several others in adjacent streets. One of the cleared houses looked as if it had been bombed. ${ }^{133}$

The arrival of non-recruited workers continued; up to 40 Moroccans per week arrived at Utrecht's municipal employment agency. All brought 500 guilders in new bills, and a discharge slip from the same garage in Brussels. Most could not read or write, and spoke no other language but their own. The discharge slip was nonsense and the 5 oo guilders they brought because some municipalities asked foreign workers to deposit this sum, to pay for their return trip. ${ }^{134}$

According to the boarding house ordinance, a permit was required if there were more than 20 lodgers. In April 1966 a permit was requested for the human warehouse' Oudegracht 234, which previously had been closed by court order, but which now again housed 55 workers. ${ }^{135}$ In 1966 , the Utrecht city council once more closed several of the large boarding houses and instructed employers to find new accommodation. Shortly afterwards, the municipality panicked. Large numbers of Turks and Moroccans arrived, and dozens of new accommodations opened their doors. Employers said they preferred 'strays' (non-recruited workers) because official procedures were too long and too

\footnotetext{
130 Refers to Nieuwe Daalstraat 32, Oudegrancht 34 and all houses owned by Simons who had been instructed to make changes to his boarding houses but did not comply.

$131 \quad$ Utrechtsch Nieuwsblad 24 November 1965.

132 Utrechtsch Nieuwsblad 3 December 1965.

133 S. van Vlerken and R. Koolen, De droom voorbij. 25 jaar buitenlanders in Utrecht (Utrecht 1990) 33 .

134 Utrechtsch Nieuwsblad 7 October 1965.

135 Bad boarding house were also found at Esdoornstraat 4, Haverstraat 30, and Loevenhoutsedijk 6. The situation in Nieuwe Kamp 16 was regarded as unacceptable; Utrechtsch Nieuwsblad 18 July 1966.
} 
costly. ${ }^{136}$ They were not responsible for housing 'strays'. The Utrecht city council asked to the ministry of Justice to reduce the number of new arrivals, and the ministry promised to keep the numbers down for the next six months. ${ }^{137}$

The situation however did not improve; places were still dirty, overcrowded and a health hazard, and rooms were let illegally. A large conference was held about guestworker migration, at which Buis represented Utrecht. Het UtrechtschNieuwsblad was the only newspaper to send a journalist. Participants agreed that the Dutch economy could not function without foreign workers, and all participants expected that most foreigners would not stay permanently. Utrecht, where 10 per cent of the foreign workers in the Netherlands lived, was regarded as one of the most problematic cities, with the worst housing situation. Workers were homesick, they missed their food, and their wives and children. Pubs refused to serve foreigners even if they were dressed properly and had shown the waiter that they had money to pay for their drink. The press was criticised for paying too much attention to crime among foreign workers, while research had shown that violence and crime were less amongst foreign workers than among the Dutch. According to Buis, guestworkers should be shown the advantages of living in a democracy; now they were not. ${ }^{138}$

Shortly afterwards, one of the Utrecht alderman appealed to the Minister of Justice and said the situation in Utrecht was getting out of hand. The large number of guestworkers - including 2000 Moroccans - that arrived made it difficult to exercise control. ${ }^{139}$ Guestworkers slept under bridges. The ministers of Justice and of Social Affairs should refuse permits, force employers to house workers, and allow housing in barracks, newspapers wrote. ${ }^{140}$ Demand for labour fell, but new workers kept coming. ${ }^{141}$

Apart from housing, also the absence of a mosque was an issue. In 1966, L.M. Simons asked permission to construct a mosque in the yard of one of his boarding houses. ${ }^{142}$ Simons was labelled one of the worst landlords, exploiting numerous boarding houses, although he did not want to disclose how many of the 3500 guestworkers in Utrecht were living in his houses. He was, in his own words, a very busy lawyer and letting rooms was only a hobby. He wanted to convert a shed into a mosque where an Iman would lead Friday prayer. Muslims living in his houses, would no longer have to pray in a closet, as they

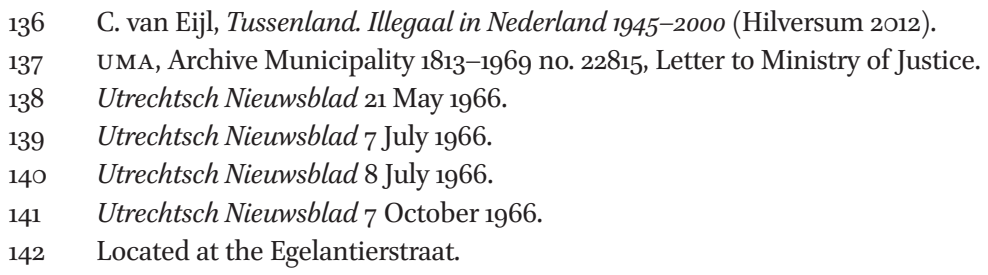




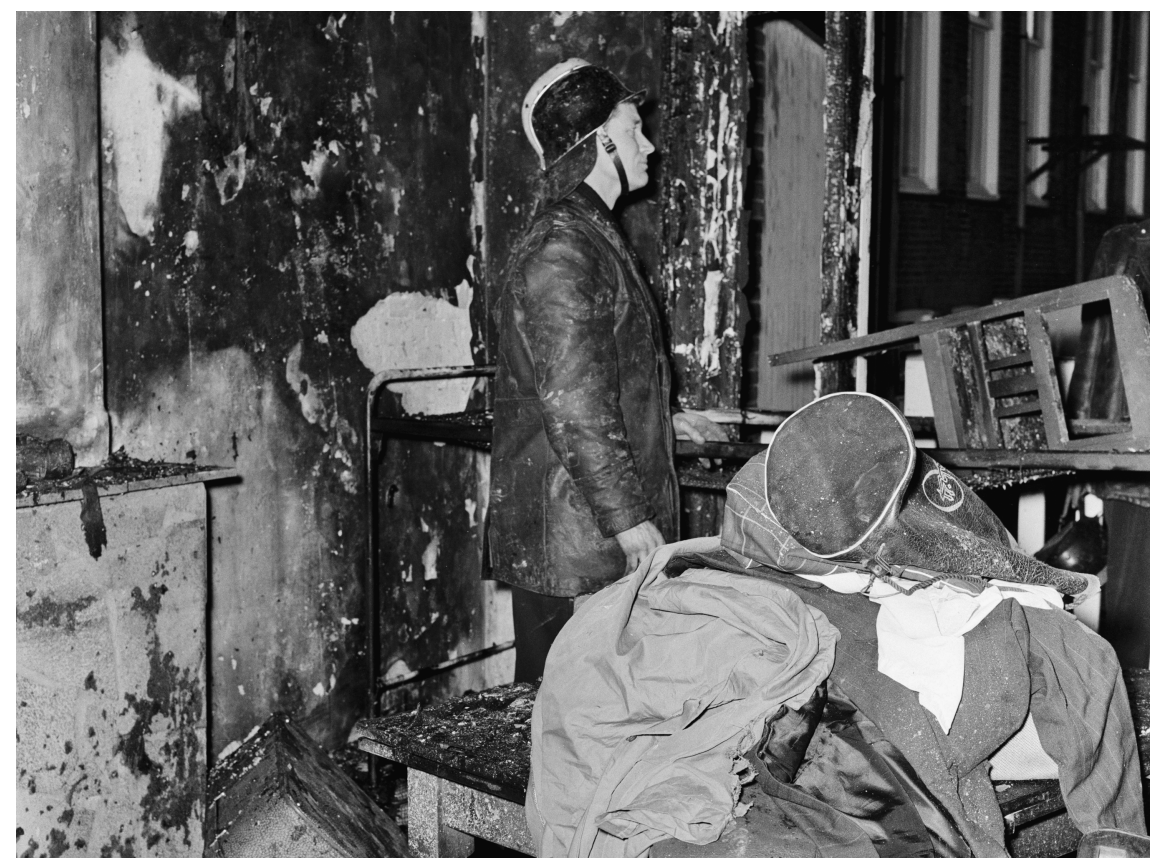

ILLUSTRATION 1 Interior of a house, in which ten or more Moroccan guestworkers lived, after a fire.

J.P. COENSTRAat 10 UtRECHT)15 MARCh 1967. Photographer. L.H. HOFLAND, THE UTRECHT ARCHIVE D 2391 -X 155818.

did now. ${ }^{143}$ The rooms he let were also unsuitable for washing up before prayer. He would construct a washing room in the mosque and put in carpets. The mosque would not generate extra income for him; it was a humanitarian gesture he said. ${ }^{144}$ Nothing came of the plan.

Large venues were rented to celebrate the end of Ramadan: in 1966 a church (the Buurkerk in the city centre) which could accommodate 300 people, and in 1968 Tivoli theatre, which could accommodate 1000 people. In 1970 Moroccans and Turks used the top floor of a former insurance firm as a mosque. ${ }^{145}$ In other rooms in that building guestworkers slept. In 1972 it was torn down. ${ }^{146}$ In 1971 there was a plan to build an Islamic Centre plus a mosque in Utrecht. ${ }^{147}$

Utrechtsch Nieuwsblad 10 October 1966; Parool 10 October 1966.

144 Telegraaf 13 October 1966; Tijd 11 October 1966; Volkskrant 11 October 1966.

145 On the Moreelselaan.

146 Theunis, Ze zien liever mijn handen, 381-382 and 391-404.

147 Located at the Weg der Verenigde Naties. 
The mosque would have a golden dome, a minaret of 6o meters, and a capacity of 7500 people. It was the plan of two Dutch men - Th. Hogtenberg and R. Kamerbeek - who had travelled to the Middle East frequently over the last 25 years, and who represented the Dutch Arab Circle. Kamerbeek build a Moorish house for himself in Utrecht, and said he was a broker for people who wanted to do business in the Middle East. ${ }^{148}$ The centre would cost 50 million guilders, 15 million of which would be spend on the mosque. ${ }^{149}$ It would include an educational centre (providing language classes), a Social Work department, 20 shops selling products missed by Muslims, an auditorium for 600 people, and exhibition room and a hotel with 200 beds. Costs should be covered by Islamic countries (including Saudi Arabia), the Utrecht municipality, the Dutch government, and firms which had recruited a large number of Muslims. Furthermore, every Muslim in Western Europe should donate 25 guilders. ${ }^{150}$ Nothing came of this plan either.

In 1973, there were 5000 Muslims in Utrecht (including 3000 Moroccans and 1600 Turks). Protestant churches were asked to help find a mosque, but they declined saying that God was not the same as Allah, and providing Muslims with room for prayer was not their task. One church made an exception and collected money for building a mosque, stating that Dutch society had brought the Muslims to the Netherlands, and therefore should solve the problem. ${ }^{151}$ Shortly afterwards a Catholic group collected 15,000 guilders for building a mosque. However, most Protestant and the Catholic communities criticised these collections: they were willing to donate money to convert Muslims, but not to provide them with a mosque. ${ }^{152}$ Attempts were made to covert the Catholic Monica church (previously used by the Poles) into a mosque. It had been built in 1886, and stood empty in the 1970s. The asking price was 2 million guilders. The Muslim community could not raise this sum and the church was torn down despite protests. In 1974 a church was converted into a mosque. ${ }^{153}$

\footnotetext{
148 Leidsch Dagblad 3 February 1968.

149 Vrije Volk 8 December 1971.

$150 \quad$ Nederlands Dagblad 10 December 1971; Limburgsch Dagblad 25June 1971; Tijd 10 December 971; Leeuwarder Courant 15 June 1971.

$151 \quad$ Nederlands Dagblad 22 September 1973.

$152 \quad$ NRC 7 November 1973.

153 NRC 23 August 1974.
} 


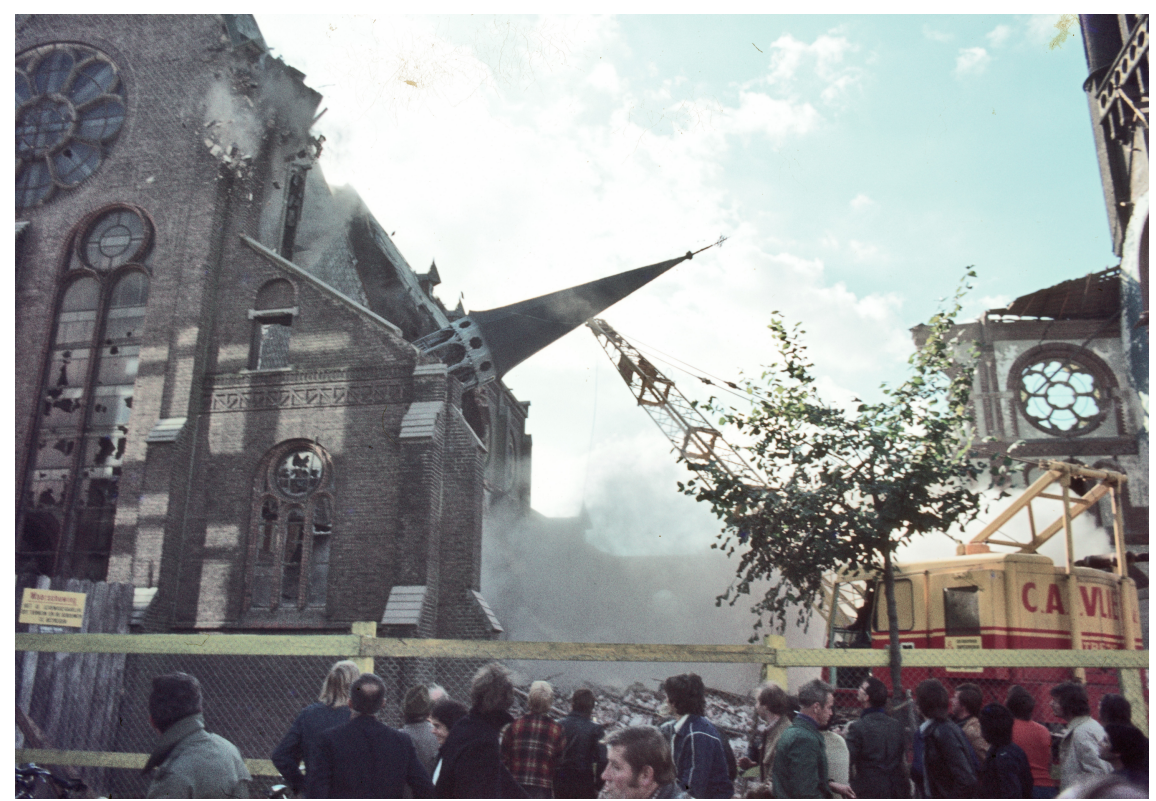

ILLUSTRATION 2 In the 1950s and 196os, mass was celebrated in the Utrecht Monica church (built in 1886) in Polish, for the Polish DP s. In 1970s Muslims tried to buy the church, which at that time stood empty and planned to convert it into a mosque. The plan failed because the asking price was too high. Shortly afterwards the church was demolished. On the picture; locals watch the demolition of the church. 1977 .

PHOtographer W.h.M. Uilenbroek. The Utrecht archive. M 7573-X 126922.

\section{Deporting Guestworkers}

In October 1966, Utrecht authorities started to deport Moroccan workers in groups of ten or more per day. The workers felt humiliated and were full of grief and anger. They had spent money to get to Utrecht, and their deposit of 500 guilders was now used to deport them. They were put in a holding cell, and treated like criminals. ${ }^{154}$ Moroccans complained they had received a warm welcome when they arrived: they were slapped on the shoulder 'Welcome Mohammed!' Now, they were deported because there no longer was any work. ${ }^{155}$

In 1965, there had been 1000 deportations across the Dutch-Belgian border, but in the first nine months of 1966 this increased to 1700 deportations. Dutch 
authorities said that Belgian border guards should have paid more attention at both the French and the Dutch border. Foreign workers were smuggled across the border via the woods, and it was impossible to check all passengers on international trains. Dutch guards stopped a car with five Moroccan men who had small amounts of Spanish, French, Belgian and Dutch money on them, and addresses of fifteen boarding houses. The police assumed, the driver had been paid to collect workers and to bring them to Tilburg or Utrecht. ${ }^{156}$

The Utrecht Chief of Police Tj.P. de Vries, feared that crime would increase if jobless foreigners were hanging around. ${ }^{157}$ Since they lived in cramped accommodations, problems would arise if they did not work. ${ }^{158}$ Foreign workers were fired before Dutch workers were, and Buis considered this unfair. People who were deported, not only lost a lot of money but also lost face in their home communities. Buis said that some deportees might have been entitled to unemployment benefits, but this had not been checked. ${ }^{159}$ He argued in favour of a 'golden handshake' for returnees, consisting of the benefits they were entitled to. This suggestion had previously also been made by J. Kuipers, chief of the Amsterdam Alien Police. ${ }^{160}$ The suggestion was not honoured. In 1967, Buis accepted a job offer in another town (no longer working for guestworkers), and Utrecht lost one of its most important and experienced claim makers on the housing issue of guestworkers. ${ }^{161}$

The city council continued to insist that it was not responsible for housing guestworkers. ${ }^{162}$ In 1969, a new black list was drafted, which again showed severe housing shortages and appalling living conditions. ${ }^{163}$ In Utrecht's old working-class neighbourhoods, the percentage of guestworkers increased to $20 .{ }^{164}$ In 1969, the popular national TV show VARA's Achter het Nieuws paid attention to guestworker housing in Utrecht. ${ }^{165} \mathrm{~A}$ journalist spoke to boarding house owner Simons, who said his guests were ungrateful and he was civilising

156 Utrechtsch Nieuwsblad, 15 October 1966.

157 Algemeen Handelsblad 19 October 1966.

158 Limburgsch dagblad 19 October 1966.

159 Parool 14 October 1966.

16o Algemeen Handelsblad 19 October 1966; Volkskrant 19 October 1966.

$161 \quad$ Utrechtsch Nieuwsblad 27 May 1967.

162 UMA, Archief gemeentebestuur 1813-1969 nr. 22815, map Vragen mevr.J.M. Donia-Brugman.

163 UMA, Archief gemeentebestuur 1813-1969 nr. 22816.

164 F. Bovenkerk e.a., Vreemd volk, gemengde gevoelens. Etnische verhoudingen in een grote stad (Meppel/Amsterdam 1985) 40.

165 E.S.M. Thomeer, Eiland binnen Utrecht. De maatschappelijke positie van Turken en Marokkanen in de Utrechtse wijk Kanaleneiland omstreeks 1980. Unpublished thesis (Utrecht 2005) 33 . 
them. They did not know chairs in their country of origin, or toilets because they were used to hole in the ground..$^{166}$

Local people came out in support; on one day in 1979, 26 houses in Utrecht were taken over by Dutch squatters, who called themselves the Nomad committee. The squatters invited Turkish families to move in, but they were evicted the same day. The action was meant to draw attention to the bad housing situation of the guestworkers rather than to solve problems in the short run. The Utrecht alderman in charge of housing promised 15 per cent of the housing stock, over which the municipality had a say, would be allocated to guestworkers, and registration forms would be translated into Turkish and Arabic. ${ }^{167}$

In the 1970s, house owners in the old city centre and adjacent neighbourhoods sold their property in anticipation of large-scale urban renewal projects. ${ }^{168}$ The original population left, but the houses were not immediately demolished. Speculators bought up properties, split them and sold them to guestworkers, while inflation drove up mortgages. According to the communist paper De Waarheid, the Dutch profited greatly from selling houses to guestworkers. ${ }^{169}$ Turks who lived in Utrecht started to act as realtors, mainly working for compatriots. The guestworkers bought houses at high prices in bad neighbourhoods because they had to have family housing when they wanted to bring their families. ${ }^{170}$ The Dutch housing market was extremely closed; families looking to rent were on a waiting list for years. Connections and insights into the allocation system - both of which the immigrants lacked - helped if you wanted to jump the queue. ${ }^{171}$ Many of the guestworkers from Morocco and Turkey had large families. According to the rules of housing corporations, a family with six children needed a seven-bedroom house. These large houses hardly became available and if they were offered, guestworkers turned them down because the rent was too high. They were unaware that they could get rent subsidies. ${ }^{172}$ Guestworkers could only bring children under the age of 18 , and therefore they could not afford to be on the waiting list for too long. It drove them to buy houses in bad, impoverished neighbourhoods. They

\footnotetext{
$166 \quad$ Nieuwsbrief Buitenlandse Werknemers 1969145.

167 R. Dettingmeijer, 'Turks Nomadenkomite kraakt massaal', Motief, tijdschrift voor wie ten dienste staat van buitenlanders 4: 7 (1978) 12.

168 Heurneman, M. en B. van Santen, De Utrechtse wijken: West (Utrecht 2003) 141.

169 'Waarheid 11 August 1972.

$170 \quad$ F.J. Ormeling, 'Karakteristieken van een bevolkingsgroep: vreemdelingen te Utrecht', Kartografisch Tijdschrift 7: 2 (1981) 3-37.

171 Bovenkerk, Vreemd volk, 49.

172 'Acceptatie van huurwoningen door migranten'. Appendix: Buitenlanders Bulletin 7:9 $(1982)$.
} 
were called emergency buyers. ${ }^{173}$ At the end of the 1970s the housing market crashed, and in the 1980 s house prices were below the price guestworkers had paid. Furthermore, the municipality declared some houses uninhabitable. This was also the moment when many guestworkers became unemployed, and the type of work for which they had been recruited disappeared permanently. ${ }^{174}$ When the emergency buyers could no longer pay their mortgage, the house was sold by the bank, and the guestworkers were left in debt.

\section{Conclusion}

According to the literature on the spatial turn approach (discussed above), some authors believe space determines social cohesion and processes of integration. Other authors, however argued that access to space does not equal community formation. In Utrecht, the housing shortage led to extensive debates about the arrival of immigrants in the whole period under study. Immigrants came to Utrecht from a large number of countries, but debates focussed on the guestworkers and their families, who formed the largest group.

This article added to the literature because it not only looked at immigrants, and their claims to space, but rather at large numbers of claim makers. In fact, the immigrant voice was absent from most of the sources. Complaints about housing (and other immigrant issues) were made by organisations that were set up for immigrants, rather than by immigrants. Organisations for immigrants were better at getting subsidies, and squeezed out initiatives by immigrants. Attempts to include migrants in the organisations failed, largely because the non-migrants who ran them sought to exclude the immigrants who did not agree with them. In addition to the representatives of organisations for immigrants, local authorities, journalists and employers played a role in housing debates. Employers tried to shed the responsibility for housing, as did the municipality. Debates were hardly about social cohesion or community formation. They were about avoiding unsanitary conditions, excessive profits and overcrowding. For the early immigrants (such as the Poles) some initiatives were taken to provide them with a place of worship. The first initiatives for mosque building were taken by non-Muslims (and failed). It took many years before there was a mosque.

Immigrant access to space changed depending on what employers did, on organisations and specific claim makers (such as Buis), on government

173 Bouras, Het land van herkomst.

174 Werkspoor closed in 1971, Hamburger in 1977 and Demka in 1983. 
regulations (such as the 5 per cent rule and rules regarding family reunification), and on changes in the demand for labour. In Utrecht the demand for labour was highly flexible (and this caused the continuous debates and the bad housing situation). After the fall in the demand for labour, the housing issue was connected to crime, disease, and potential riots. This article showed immigrants lived where they were housed, or where they could afford to or were allowed to live. Choice had very little to do with their access to space. Theories that equate access to space with social cohesion and community formation, overestimate the element of choice. 